\title{
The Chilean Health System: 20 Years of Reforms
}

Annick Manuel, MD, MPH.(1)

\section{Manuel A. \\ The Chilean Health System: 20 Years of Reforms. Salud Publica Mex 2002;44:60-68. The English version of this paper is available too at: http://www.insp.mx/salud/index.html}

\begin{abstract}
A bstract
The Chilean health care system has been intensively reformed in the past 20 years. Reforms under the Pinochet government (1973-1990) aimed mainly at the decentralization of the system and the development of a private sector. Decentralization involved both a deconcentration process and the devolution of primary health care to municipalities. The democratic governments after 1990 chose to preserve the core organization but introduced reforms intended to correct the system's failures and to increase both efficiency and equity. The present article briefly explains the current organization of the Chilean health care system. It also reviews the different reforms introduced in the past 20 years, from the Pinochet regime to the democratic governments. Finally, a brief discussion describes the strengths and weaknesses of the system, as well as the challenges it currently faces. The English version of this paper is available too at: http://www.insp.mx/salud/index.html
\end{abstract}

Key words: health systems; health care reform; C hile

\begin{abstract}
Manuel A.
El sistema de salud chileno: 20 años de reformas. Salud Publica Mex 2002;44:60-68.

El texto completo en inglés de este artículo también está disponible en: http://www.insp.mx/salud/index.html
\end{abstract}

\section{Resumen}

El sistema de salud chileno ha sido intensamente reformado en los últimos 20 años. Las reformas bajo el gobierno de Pinochet (1973-1990) apuntaron principalmente a la descentralización del sistema y al desarrollo del sector privado. La descentralización involucró un proceso de desconcentración y la devolución de las unidades de atención primaria a las municipalidades. Los go biernos demo cráticos posterio res a 1990 escogieron preservar el núcleo organizacional, pero las reformas introducidas buscaron corregir las fallas del sistema y aumentar la eficacia y la equidad. El presente artículo explica brevemente la organización actual del sistema de salud chileno y revisa las diferentes reformas introducidas en los últimos 20 años desde el régimen de Pinochet hasta los go biernos democráticos. Finalmente, presenta una discusión breve para describir las fortalezas y debilidades del sistema, así co mo los desafíos que enfrenta actualmente. El texto completo en inglés de este artículo también está disponible en: http://www.insp.mx/salud/index.html

Palabras clave: sistemas de salud; reforma del sistema de salud; Chile
C hile has a total area of $757,000 \mathrm{~km}^{2}$, covering a nar row strip of land between the Andes and the South Pacific, and an estimated population of 15 million. This corresponds to a population density of 20 habitants per $\mathrm{km}^{2}$, but with great variation, since $84 \%$ of the population live in urban zones and $40 \%$ in the Santiago metropolitan area.
Chile is an upper-middle-income country with a gross national product (GNP) of US\$ 74 billion in 1998 and a GNP per capita of US\$ 4,990, which ranked the Chilean economy $42^{\text {nd }}$ and $66^{\text {th }}$ in the world, respectively. ${ }^{1}$ In the last decade Chile presented an average economic growth rate of $7.9 \%$-almost twice the average annual growth of the previous decade-, which

(1) Centro de Investigación en Sistemas de Salud, Instituto N acional de Salud Pública, Cuernavaca, Morelos, México.

Received on: January 8,2001 • Accepted on:A ugust 15, 2001 
helped to reduce poverty from $45 \%$ in 1987 to around $20 \%$ nowadays. ${ }^{2}$ However, Chile still stands as one of the countries with the worst income concentration. ${ }^{3}$ The unemployment rate also fell considerably during the nineties, from $10 \%$ in 1986 to $5.5 \%$ in $1996,{ }^{2}$ but increased again to reach $8.2 \%$ in the first trimester of 2000. Regarding education, the adult literacy rate is $95 \%$ and the average length of schooling, almost 10 years. ${ }^{4}$ Finally, Chile ranks $38^{\text {th }}$ worldwide according to the 2000 Human Development Index of the UNDP, after Argentina $\left(35^{\text {th }}\right)$ and before the other middle-income countries in Latin America.

\section{Health Conditions}

Chile, along with Cuba and Costa Rica, exhibits the best health indicators in Latin America. The decline of general and infant mortality rates has greatly increased life expectancy at birth and modified the population age structure. Infant mortality rates decreased from 82 per 1000 live births in 1970 to only 10 in 1997, ${ }^{1}$ a figure comparable to that of many European countries. Life expectancy increased from 63.5 years in 1970 to 75.4 in $1999,5,6$ which changed the age distribution of the population. Chile's demographic changes have been accompanied by an epidemiological transition that involves the coexistence of chronic diseases of increasing prevalence and communicable diseases representative of poor nations (Tables I and II).

\section{Health System}

\section{Delivery of health services}

The Chilean health system has a public and a private component. The public component covers around $60 \%$ of the population, basically the urban and rural poor, the lower middle-class, and the retirees. The financing part is administered by FONASA (National Health Fund or Fondo Nacional de Salud) and delivery is ensured by the National Health Services System or Sistema Nacional de Servicios de Salud (SNSS) and the Municipal System for Primary Care. A small proportion of the Chilean population-around $10 \%$-is covered by other public agencies (Army Health Services, Universidad de Chile). The private sector includes basically the private health plans administered through the Health Provision Institutions or Instituciones de Salud Previsionales (ISAPREs) that offer services to around $25 \%$ of the population, mostly the upper-middle class. A parallel private system exists for occupational injuries and diseases; three not-for-profit Mutuales insure and provide health services to more than 2.5 million workers.

\section{Table I \\ BASIC DEMOGRAPHIC AND HEALTH INDICATORS. ChILE 1970, 1982, 1992, 1997}

$\begin{array}{lllll}\text { Indicators } & 1970 & 1982 & 1992 & 1997\end{array}$

\begin{tabular}{lrrrr} 
Life expectancy & 63.6 & 71.3 & 72.2 & 75.3 \\
\hline Total fertility rate & 3.4 & 2.8 & 2.6 & 2.5 \\
\hline \% population growth & 1.8 & 1.8 & 1.6 & 1.3 \\
\hline \% population 0-14 & 39.2 & 32.2 & 29.4 & 28.6 \\
\hline \% population $>65$ & 5.0 & 5.8 & 6.6 & 7.0 \\
\hline General mortality rate & 8.7 & 6.1 & 5.5 & 5.4 \\
\hline Infant mortality rate & 82.2 & 23.6 & 14.3 & 10 \\
\hline Maternal mortality rate & 1.72 & 0.4 & 0.31 & 0.23 \\
\hline \% medicalized births & 85.1 & 96.5 & 99.2 & 99.5
\end{tabular}

Per 1000 live births

Source: Instituto $\mathrm{N}$ acional de Estadística, Chile

\section{Table II Main CAUSES OF DEATH. ChILE, 1970, 1982, 1992, 1997}

\begin{tabular}{lrrrr} 
Causes & 1970 & 1982 & 1992 & 1997 \\
Cardiovascular diseases & $22.3 \%$ & 27.6 & 29.0 & 26.4 \\
\hline Malignant tumors & 12.0 & 16.8 & 20.0 & 21.7 \\
\hline Injuries & 19.0 & 12.1 & 12.0 & 10.6 \\
\hline Respiratory diseases & 17.4 & 8.5 & 11.1 & 12.7 \\
\hline Digestive diseases & 6.9 & 8.6 & 6.3 & 7.5 \\
\hline II-defined causes & 4.5 & 8.8 & 5.6 & 4.7 \\
\hline Infectious and parasitic diseases & 10.9 & 3.8 & 2.9 & 3. \\
\hline Perinatal causes & 5.0 & 3.5 & 1.9 & 1.3 \\
\hline Others & 2.0 & 10.3 & 11.2 & 12.0
\end{tabular}

Source: Instituto N acional de Estadística, Chile

The public system includes the Ministry of Health (MH) and five semi-autonomous bodies created in 1980 (although the Superintendencia of the ISAPREs was created in 1990): the SNSS, FONASA, the Public Health Institute, the Procurement Center or Central de Abastecimiento (CENABAST) and the ISAPREs Superintendence.

The role of the $\mathrm{MH}$ includes ensuring Chilean citizens free and equal access to health services and programs, and their free choice between the public and private health services. The $\mathrm{MH}$ establishes national health policies, plans, and norms according to government directives and rules listed in the Sanitary Code; also, it supervises the five organizations that compose the public health sector. In fact, although they are ad- 
ministratively autonomous, these bodies must exercise their function in accordance with the dictate of the $\mathrm{MH}$. The SNSS includes 28 Regional Health Services that cover the whole territory; it provides health promotion and protection plans to patients, as well as health care services (mainly second and tertiary care), through a network of hospitals and health posts. FONASA is the financing body of the public sector. It collects, administers and distributes various financial resources. The Public Health Institute is the national reference center for public health issues; it supervises the public laboratories and is also in charge of all issues related to drugs and medicines (authorization, quality, importation). CENABAST controls the purchase and delivery of all drugs, supplies and medical equipment for the SNSS. Finally, the ISAPREs Superintendence regulates the private institutions called Instituciones de Salud Previsionales or ISAPREs.

Most of primary health care in Chile is provided through the Municipal Primary Health Care System. However, the $\mathrm{MH}$, through the Regional Health Services, supervises the delivery of primary care and ensures that primary health care facilities comply with the $\mathrm{MH}$ technical norms. ${ }^{7}$

Regarding the private component, the ISAPREs are private institutions that collect and administer the mandatory health contribution from the citizens who choose to be insured by the private sector instead of FONASA. ISAPREs offer health plans on an individual basis to these members and their families, and the benefits are freely determined by both parties. In addition to the mandatory contribution, members can decide to pay a complementary contribution to have access to additional benefits. There is a multitude of health plans providing different ranges of medical services. However, ISAPREs have the legal obligation to cover, in all plans, the following: ${ }^{8}$ i) preventive medicine exams; ii) sickness pay insurance; and iii) protection for pregnant women and children aged under six years.

For the ISAPRES, health contracts are lifetime agreements, unless the member fails to comply with his/her financial obligations. Individuals can terminate the contract once a year on the contract anniversary, with a month's advance notice. The ISAPREs provide outpatient and inpatient services through their own clinics and hospitals or, mainly, through contracted private or public facilities. The level of freedom of choice for the affiliated varies according to the plans.

\section{Health care financing}

Overall, Chile spends $6.1 \%$ of its GDP on health; half of it is public (49\%) and half private (51\%), most of it out-of-pocket. ${ }^{9}$ Per capita expenditure amounts to US\$ 315 , a figure greater than that of Mexico (US\$240) and Venezuela (US\$150), similar to that of Brazil (US\$ 319), and smaller to that of Argentina (US\$ 676) and Uruguay (US\$ 660).

Since 1981, all employees and retirees make a health contribution equal to $7 \%$ of their taxable revenue, up to a top limit. This contribution is optional for the self-employed. The workers can choose to pay this mandatory contribution to FONASA or to an ISAPREs.

As was mentioned before, FONASA is a public agency in charge of financing the health services of the public sector. The resources of this agency come mostly from general taxes, the mandatory contribution and copayments, and they finance the SNSS and the municipal services.

SNSS health facilities receive "diagnosis-basedpayments" from FONASA for the most frequent pathologies and a "prospective-payment-for-service" for other diagnoses. Municipal facilities funding is based on a per-capita system that takes into account the registered population, its socio-economic characteristics (rurality and poverty), and the volume of services effectively delivered.

Citizens affiliated under the "institutional modality" -basically the poor who make no mandatory contribution- cannot choose their provider and receive care only from public facilities. Copayments are related to the income level and are equal to 0,10 or $20 \%$ of the price of the service. Beneficiaries making the mandatory contribution can use the "institutional modality" or the "free-choice modality". Under this pre-paid free choice provider system, users can choose private providers and the copayment rate depends on the level of quality of the providers. Three groups exist and providers register themselves into the group of their choice.

The funds of the ISAPREs, on the other hand, come from the mandatory contribution, additional voluntary contributions of the members of the formal economy and voluntary contributions of the self-employed, the $2 \%$ contribution paid by employers for some low-income employees, and copayments.

\section{Health Reforms}

Health Reforms of the Pinochet Era (1973-1990)

The foundations of the current health system were designed and implemented during the Pinochet era. The democratic regimes that followed introduced some changes, but chose to preserve the core of the system. Moreover, some of the changes were aimed at strengthening the efficiency of the achieved decentra- 
lization. They have also maintained the coexistence of the public and private sectors and have reinforced the regulatory role of the State.

Until the late 1970s, two parallel public systems coexisted. ${ }^{10, *}$ The National Health Service (SNS), funded by tax revenues and payroll contributions, covered blue-collar workers and indigents who received medical services and medicines free of charge. These groups represented $60 \%$ of the population. The National Medical Service for the Employees (SERMENA), financed through payroll contributions and out-ofpocket payments, covered white-collar workers who had also access to private providers through a preferred provider program (25\% of the population). Finally, the military health system covered $5 \%$ of the population and the private sector $10 \%$.

In 1979, however, a set of reforms consistent with the new regime's ideology was designed. These reforms aimed basically at the decentralization of the system and the development of a private sector (Figures 1 and 2).

Decentralization of the health system

Law 2763, adopted at the end of 1979, redefined the structure of the public sector. It fused the existing SNS and SERMENA into a single body, the National Health Services System (SNSS). The SNSS was composed of

* Castañeda T. Health sector reforms in Chile: Deconcentration of hospitals services and decentralization of primary health care. 1997. Unpublished. the $\mathrm{MH}$ and the dependent organizations created to achieve deconcentration ${ }^{11}$ (currently, the term SNSS refers to the health care providers network only). The law also separated the normative, financial and delivery functions within the system.

The $\mathrm{MH}$ retained the normative function, defining the health policies and programs and coordinating the interactions among the different actors and organizations of the health sector. It also controlled these different bodies, continued to supervise and evaluate the health programs, and prepared and allocated the budget.

Deconcentration led to the creation of 26 regional health services covering the whole territory and responsible for the delivery of health services (a $27^{\text {th }}$ service was responsible for environmental health hazards). These decentralized units are in charge of health promotion and protection plans, and deliver health care services to patients through a network of hospitals and health posts. Although they have an important administrative autonomy, they have to follow the rules and instructions of the $\mathrm{MH}$.

Law 2763 delegated the financial function to a new organization, the Fondo Nacional de Salud or FONASA, which replaced both SNS and SERMENA financial services. FONASA is responsible for collecting, administering, and distributing the public financial resources allotted to the health sector. It is a legally autonomous body with its own employees, but has to exercise its financial role according to the rules, plans and policies established by the $\mathrm{MH}$. Two other organizations were also created at that time, the National Institute of Public Health and the Procurement Center (CENABAST).

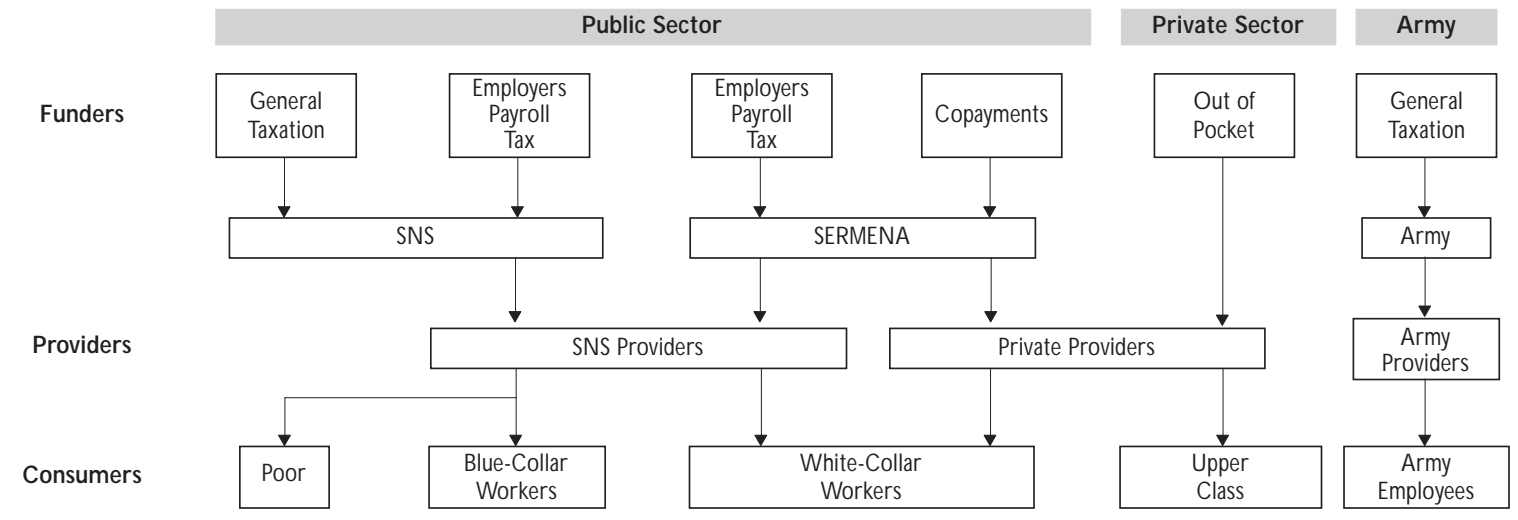

SN S: Servicio N acional de Salud ( $N$ ational Health Service)

SERMEN A: Servicio Médico N acional para Empleados ( $N$ ational Medical Service for Employees)

Figura 1. Chilean Health Care System in the pre-Pinochet era 




SS: Servicios de Salud (Regional Health Services)

SN SS: Sistema N acional de Servicios de Salud (N ational Health Services System)

Figura 2. Chilean Health Care System in the Pinochet and post-Pinochet era

The second major part of the decentralization process of the public sector was initiated in 1981 (DFL No 1). It represented the devolution of primary care centers' administration from the SNSS to the 341 municipalities throughout the country. The main objectives of the devolution of primary health care were: i) to transfer decision-making power to the local level; ii) to allow health programs to be more adapted to local population's needs; iii) to increase community participation in the health care sector; iv) to mobilize local resources for improving the infrastructure and functioning of primary care centers, and v) to allow improved coordination among social programs (health, education) at the local level., ${ }^{* 12}$ The transfer of control of the primary care sector to the municipalities occurred in two waves during the eighties, in 1981-1982 and in 1987.

The agreement between a municipal government and the local representative of the SNSS had a fiveyear duration. The agreement defined the responsibilities and duties of both parties. Municipalities were required to provide primary care and additional health

\footnotetext{
* Castañeda T. Health sector reforms in Chile: Deconcentration of hospitals services and decentralization of primary health care. 1997. Unpublished.
}

services such as vaccinations, while public facilities dependent on the SNSS had to provide secondary and tertiary care to patients referred to them by primary care municipal centers. Municipal governments had to comply with the norms and programs still centrally established and supervised by the $\mathrm{MH}$, and the local representatives of the SNSS, the Servicios de Salud, were responsible for providing technical assistance to the municipalities.

An additional significant reform related to decentralization was the change in the financing mechanisms of the public sector providers. Until 1978, public providers received a budget related to their needs and the population served. The reform intended to establish a closer relation between funding and quantity of services provided. In 1978 a Payment for Rendered Service System (Facturación por Atención Prestada or FAP) was introduced and hospitals were reimbursed retrospectively based on a list of prices for medical interventions. Similarly, the Payment for Rendered Services per Municipality System (Sistema de Facturación por Atención Prestada por Municipalidades or FAPEM), reimbursed municipal centers according to a list of fees-for-service for primary care procedures. Due to an explosion in costs, however, a ceiling was established in 1983 for each municipality on a case-by-case basis. $^{10}$ 
Development of a private sector

The ideological principles of the military regime allowed and favored the development of a private sector. The idea was to grant citizens the choice to make their mandatory health contribution either to the public financing institution (FONASA) or to private entities. The existence of such a private sector would guarantee freedom of choice and would supposedly rely on competition to ensure an efficient management of health resources.

Law Decree Number 3, enacted in 1981, legalized and defined the status and functions of those private entities called Instituciones de Salud Previsionales or ISAPREs..$^{13}$ The health plan approved by the affiliated and the institution defined the medical and economic benefits provided, as well as the premium value. The contract was established every year and the ISAPREs had the right to decline members or deny their renewal. This right opened the door to extensive selection of risks.

During the 1980s, the government made several adjustments to these initial rules:

- The mandatory contribution to the fund, which was initially fixed at $4 \%$ of the taxable revenue, was raised to $6 \%$ and to $7 \%$ in $1986 .{ }^{14}$

- In 1986, Law 18.469 created the General Benefits Regime (Regimen General de Prestaciones), which defined the rights and responsibilities of the citizens in the public sector and established the legal basis of the relationship between the ISAPREs and the public sector (FONASA, SNSS).

- In the initial years, because of the financing of the system, the ISAPREs were only accessible to highly paid workers. In 1989, Law Number 18.566 introduced the additional contribution of $2 \%$ of the taxable revenue. This contribution is to be paid by the employer, is tax-deductible, and supposedly allows the middle-class access to the private health sector.

- In 1986, the payment of the "maternal subsidies" was transferred from the ISAPREs to the State. This measure ended the private institutions' discrimination against young women. ${ }^{14}$

- Eventually, Law 18.933 was enacted in March 1990 and created the ISAPREs Superintendence. This new body replaced FONASA in the supervision and control of the ISAPREs. The new Law also regulated the minimum provisions of the health plans, the benefits excluded and the period of exclusion. Moreover, it changed the terms of the contract: until 1990 the contract was annual; this allowed ISAPREs to refuse high-cost members' contract renewal. The new law has made the contract lifelong and ISAPREs can end it only if the affiliated neglect their financial obligations. However, it can annually re-establish the benefits and prices of the contracts, provided that the new conditions apply to all the affiliated of a given plan and do not lead to the discrimination of high-cost members. $^{13}$

\section{Reforms of the Democratic Governments}

The transition government found a series of problems reminiscent of the Pinochet government. One of them was the major deterioration of public infrastructures and quality of care due to an important decline in public health expenditures during the previous decade. The national government's contribution to public health revenue had declined from $50 \%$ in 1980 to $40 \%$ in 1990 while the beneficiaries' share had increased from $36 \%$ to $47 \%$. The poor quality of public infrastructure was accompanied by inefficient management in the deconcentrated organizations, particularly the regional health services. The situation was attributed to the inadequacy of the information and administrative systems, inexperienced decision-makers, and inefficient allocation of public resources due to the centralized system of payment and fixed structure of personnel. Indeed, the FAP system did not favor efficiency and cost-containment, and the number of health workers and their salaries were fixed by law for each Servicio de Salud. This system of organization did not suit local needs.

The municipalization of primary care facilities caused other drawbacks in the system. First, there was a lack of coordination between the health services and the municipalities' authorities. Second, work conditions, wages, and career opportunities of primary care workers deteriorated, since they were governed by the private sector labor code, and this led to conflicts and lack of motivation. Third, the FAPEM method of payment, and particularly the ceiling of expenditure for each municipality introduced in 1982, resulted in many disadvantages. FAPEM prices, which were supposed to cover all costs, were underestimated and did not reflect the real costs of the services; ceilings were insufficiently adjusted for inflation and increase of medical costs. As a result, municipalities were

\footnotetext{
* Castañeda T. Health sector reforms in Chile: Deconcentration of hospitals services and decentralization of primary health care. 1997. Unpublished.
} 
under-reimbursed and municipal expenditures toward primary care progressively increased to reach $34 \%$ of the total primary care expenditure in $1993 .{ }^{*}$ Due to their inability to find new resources, poor and rural areas were most affected by the municipalization of primary care financing and witnessed an eventual deterioration in their level of health expenditure and therefore in the quantity and quality of services provided. Other disadvantages of the FAPEM payment system included the lack of incentives for quality and cost-containment, and favored curative over preventive care, since most health promotion and prevention services were not reimbursed.

The private sector grew considerably during the eighties. In 1990, 16\% of the citizens were beneficiaries of an ISAPREs. That year, Law 18.933 was adopted and granted more protection to the consumers. This event was followed by an important growth in the number of members which reached $25 \%$ of the Chilean population in 1995 (workers and families). ${ }^{14}$ However, the private system still lacked transparency because of the multiplicity of plans and prices and the absence of clear rules concerning benefits excluded, refusal of coverage or use of the excess of contribution (i.e. the amount paid in addition to the mandatory one). It also favored inequity because of the weak regulation concerning ISAPREs ability to discriminate risks. In fact, even nowadays $3.2 \%$ of the patients covered by the ISAPREs are 60 years of age or older, as compared with $12 \%$ of the patients seen at public facilities. ${ }^{15}$ Law 18.933 was a first attempt to mitigate the private sector's tendency to favor low risk individuals.

To resolve the health sector's problems, the transition government of Patricio Alwyn (1990-1994) chose to maintain the main structure of the health sector (decentralization and coexistence of private and public sectors) while strengthening the regulatory role of the state. ${ }^{16}$ The objectives of that government's reforms were to increase the equity and efficiency of the decentralized public system, and to foster community participation. ${ }^{8}$ However, the implementation of several of these initiatives was delayed until the second democratic government (1994-2000).

\section{Investments in the public system}

Owing to the deterioration of the public infrastructures a significant increase in public health expenditure was instigated, with a 50\% increase in the national

\footnotetext{
* Castañeda T. Health sector reforms in Chile: Deconcentration of hospitals services and decentralization of primary health care. 1997. Unpublished.
}

health budget over a period of four years. A national program of investment in infrastructure and equipment in public hospitals was conducted, for a total of US\$ 500 million over six years. ${ }^{17}$ Financial resources for these investments were provided by the state and through grants and loans from foreign democracies.

Focus on primary care

Important investments were made in primary care to improve the efficiency and quality of the municipalized primary care facilities, and population's access to health services. The supervisory role of the regional health services concerning primary care issues was reinforced, to correct the lack of coordination between health services and municipalities. A Division of Primary Care was created in the $\mathrm{MH}$; its role was the elaboration of plans and strategies to improve the development and quality of primary care services in health centers. A Program for the Reinforcement of Primary Care was implemented and a Project for Rural Health financed the improvement of health services management in rural areas of low population density. ${ }^{18}$

Important strikes of health care personnel in 1990 resulted in a Law that granted primary care workers a new status, replacing the private sector labor code governing them. It assigned them a centrally determined pay scale and provided career opportunities as part of a global program of workers re-evaluation.

Finally, a complete change of the financing mechanisms was progressively implemented during the nineties (see below).

\section{Administrative modernization of the public system}

The new governments also chose to strengthen the normative and regulatory role of the State, creating new Divisions at the $\mathrm{MH}$, and to improve the efficiency of the decentralized bodies. Various measures were taken to improve efficiency in the Servicios de Salud and public hospitals. For example, "Participation Committees" were created to increase staff involvement in hospital management. Efforts were aimed at increasing the Servicios de Salud decision-making autonomy concerning local investments; they were also aimed at improving working conditions, salaries and careers opportunities for health workers.

\section{Reform of the financing systems}

As mentioned above, the retrospective payment systems of FAP and FAPEM involved disadvantages that included lack of incentives for quality and cost-con- 
tainment. Prospective financing mechanisms were introduced in the nineties to improve the efficiency of public health providers. Health centers and hospitals of the SNSS are, since 1994, financed according to a Diagnostic Related Group system for the most frequent diagnoses, combined with a Prospective Payment for Rendered Service for less frequent procedures. For municipalized primary care facilities, a per-capita system based on the registered population in each health center has replaced the FAPEM system since 1997.

\section{Regulation of the private sector}

Private sector issues were the subject of an intense debate during the first years of the democracy and, as a result, Law 19.381 concerning the ISAPREs was not enacted till 1995. It strengthened the regulatory role of the Superintendence. It strictly regulated exclusion periods as well as benefits excluded. It specified the contents of health contracts and the obligations of the ISAPREs. Finally, it stipulated that the contribution excess remained the propriety of the affiliated, must be kept on an individual account, and can be used by the beneficiary for specified health purposes.

The main modification to this Law since 1995 was Law 19.650, enacted in December 1999. It initiated the progressive elimination of the tax-deductible employer's contribution that benefits mostly employers and middle-income workers. Its elimination intends to target public expenditure better. Another very recent innovation is the agreement reached by the superintendence and the ISAPREs to include catastrophic disease coverage in the private plans. Most ISAPREs have begun to offer such coverage, for an extra-fee.

\section{Challenges of the Chilean Health System}

The World Health Report 2000 analyzing health systems shows a globally favorable performance of the Chilean health system. Out of 191 countries, Chile is ranked $33^{\text {rd }}$ for the overall health system performance, $23^{\text {rd }}$ for the level of health, and $1^{\text {st }}$ for the equity in distribution of health conditions. However, the injustice of the system concerning financial contribution is obvious, with a $168^{\text {th }}$ position for fairness ranking.

Chilean health indicators are among the best in Latin America and close to those of industrialized countries. This is generally explained in the literature by the various governments' commitment toward maternal and childcare since the fifties, as well as improvement in education and sanitation systems.

However, one of the important challenges faced by decision-makers is to redefine public health priorities according to the new epidemiological profile of the country. The Chilean population is aging and the prevalence of chronic diseases is increasing. Albala ${ }^{6}$ noted in 1995 that most of the programs still focused on maternal and child health, without policies related to other population groups. Some changes seem to have been implemented since then, with more preventive and early detection programs (cardiovascular health program, early detection of breast and cervical cancer) or programs focused on the elderly. Further efforts to adapt the health system to epidemiological changes, such as a stronger focus on risk factor prevention, is a necessary component of current and future public health policies.

Other challenges involve the actual implementation of the reform to improve health sector equity and efficiency (discusion based on Carciofi et al and Larrañaga. ${ }^{19,20}$ The Chilean health system provides health coverage to $100 \%$ of the population and appropriate access is ensured by the extended network of public facilities across the country. However, there are considerable disparities in the extent and quality of health coverage. Rich people are enrolled in ISAPREs and receive better health benefits. The poor can only afford the public sector with its lower coverage and quality.

The dual system is also the source of risk discrimination since ISAPREs can freely adapt premiums to health risks. In the private sector premiums are 2.5 to 5 times higher for elderly than for young people. Greatest risks are equally discriminated. Copayments also contribute to these inequities. Annually, around $24 \%$ of patients covered by ISAPREs receive services in public facilities because they cannot afford copayments for certain interventions.

Inequity of the system comes also from an unfair financial contribution mechanism. The fact that citizens can choose to pay their contribution to the private sector instead of the public prevents the existence of a redistribution mechanism within the health sector. The highest income strata do not contribute to the public sector, except through the general taxes, part of which go to FONASA. The subsidy of health care for the poor is thus (partly) ensured by the contributions of the middle and lower classes that remain in the public sector.

The Chilean health system also suffers from inefficiencies characteristic of public and private sectors. In the private sector, competition between ISAPREs and the mobility allowed to the affiliated, who can easily change of institution, result in a system of shortterm contracts. This leads to underprovision and coverage of preventive medicine by ISAPREs that may not benefit from preventive strategies in the long term. Although they have the obligation to provide regular 
check-ups to affiliates, they do not encourage their use and, as a result, expenditure for preventive medicine represented only $0.2 \%$ of the total ISAPREs expenditures in 1994. Other consequences of competition and mobility in the private sector are the high administrative and marketing costs. Moreover, even though the Laws enacted in 1990 and 1995 tried to increase regulation, the absence of clarity and overabundance of health plans result in consumers' lack of information. In 1995, 8800 different plans existed in the private sector, making comparisons difficult for consumers. Finally, the retrospective fee-for-service mode of payment usually used in the private sector induces demand and has no incentives for cost containment.

The public sector is not free of inefficiencies either. FONASA still lacks reliable information on the beneficiaries even if some progress have been made. The collection of copayments is made difficult since there are knowledge gaps regarding people's ability to pay. Moreover, it is common for ISAPREs beneficiaries to use public sector resources for expensive procedures not covered by their private health plan. Low efficiency in the production of health services is another problem. For example, the $70 \%$ increase in public expenditures for health, in the early nineties, did not increase production nor satisfaction levels of the population. Both municipal facilities and hospital authorities lack legal authority and autonomy for the most efficient management of resources, particularly human resources.

To specifically address problems due to the decentralization of primary care, some reforms have been introduced in the nineties. Reforms focused particularly on the unequal and inefficient financing system, and on the personnel status that was a source of demotivation and conflict. Some problems seem to persist, such as the status of primary care facilities and personnel in the public network, lack of coordination between primary care centers and hospitals -leading to inefficient management and delivery- and lack of integration of primary care personnel in the public career system, which results in their demotivation and high mobility.

Last but not least, dissatisfaction of the Chilean population is high with regard to both the private and public sector. A study done in 1994 by the Center for Public Studies showed that 55\% of public sector and $45 \%$ of private sector beneficiaries were dissatisfied or very dissatisfied with their health system.

\section{Acknowledgements}

Many thanks to Octavio Gómez-Dantés (INSP, México), Edmundo Beteta (Universidad de Chile) and Raúl
Koch Barbagelata (SEREMI de Salud X Región, Chile) for reviewing the article and making invaluable comments and suggestions. This article has been written while the author was participating in the International Clearinghouse of the Health System Reform Initiatives.

\section{References}

1. World Bank. World Development Indicators 2000. W ashington D.C.: World Banck. A pril 2000.

2.PAHO.D ivision of health systems and services development. Chile:Profile of the health services system.W ashington, D.C.: PAHO , 1999.A vailable at http://www.americas.health-sector-reform.org/english/clhmchipr.htm Consulted in August 2000.

3. Székely M. La desigualdad en México: una perspectiva internacional. Superación de la pobreza. Diálogos nacionales. W ashington, D.C.: Inter American Development Bank; 2000:45-74.

4. PAHO. Chile. Health in the Americas. Washington, D.C.: PAHO, 1998;ll:163-180.

5. Instituto Nacional de Estadísticas. Santiago de Chile: INE 200. Chile. Estadísticas Demográficas. Available at: http://www.ine.cl/chile_cifras/ f_chile_cifras.htm. Consulted on August 2000.

6. Albala C,Vio F. Epidemiological transition in Latin America:The case of Chile. Public Health 1995;109:431-442.

7. Ministerio de Salud. Division of Primary C are. Santiago de C hile: Ministerio de Salud, 2000.Available at: www.minsal.cl C onsulted on August 2000. 8. González-Reyes JL. Atención de la Salud en Chile. Santiago de Chile. Editorial Antártica S.A, 1995

9. World Health O rganization. The World Health Report 2000. Health Systems:Improving performance. G eneva:W orld Health 0 rganization;2000. 10. Bossert T, Larrañaga 0 , Infante A, Beauvais J, Bowser D. Applied research on decentralization of health systems in Latin America. Chile case study. D ata for decision-making project. Boston: Harvard School of Public Health, 2000.

11. Beteta E, C abezas M, Ferrecio C, Larrañaga 0, 0 yarzo C, Sanhueza R. Evaluación del proceso de reforma del sector público de salud chileno: una experiencia de 20 años. Santiago de Chile. Instituto de Economía, Universidad de Chile, 1998.

12. D uarte $D$.A signación de recursos financieros al sector municipalizado de salud. Papeles de Trabajo Núm. 29. Santiago de Chile: Corporación Tiempo 2000. Programa de Estudio Prospectivo; 1993.

13. Callund J. Health care in Chile. Benefits Compensation Int 1992 June; 14-22.

14. Q uesney F. El sistema privado de salud. Las ISAPRES: hacia la modernidad en salud. Santiago de Chile. Asociación de ISA PRES, A.G., CIED ESS 1996; 97-116.

15. Stocker $\mathrm{K}$, W aitzkin $\mathrm{H}$, Iriart C. The exportation of managed care to Latin America. N Engl J Med 1999;340(14):1131-1136.

16. Bossert T. Lessons from the Chilean model of decentralization: D evoIution of primary care to municipal authorities ed: USAID Latin A merican and Caribbean Health and Nutrition Sustainability Project, 1993; Policy Report № 1 .

17. Jiménez de la Jara J, Bossert T. C hile's health sector reform: Lessons from four reform periods. Health Policy 1995;32:155-166.

18. Azevedo AC. La provisión de servicios de salud en Chile: aspectos históricos, dilemas y perspectivas. Rev Saude Publica 1998;32(2):192-199. 19. Carciofi R, C etrangolo O, Larrañaga 0 . Desafíos de la D escentralización: educación y salud en A rgentina y Chile. Santiago de Chile. N aciones Unidas, Comisión Económica para América Latina y el Caribe; 1996.

20. Larrañaga 0 . Eficiencia y equidad en el sistema de salud chileno. $\mathrm{N}$ aciones Unidas, Comisión económica paraA mérica Latina y el C aribe, 1997. 